\title{
STEM-Based Learning Analysis to Improve Students' Problem Solving Abilities in Science Subject: a Literature Review
}

\author{
Nurul Heni Astuti ${ }^{1 凶}$, Ani Rusilowati ${ }^{2}$, Bambang Subali $^{2}$ \\ ${ }^{1}$ SMP N 1 Banyubiru, Indonesia \\ ${ }^{2}$ Pascasarjana, Universitas Negeri Semarang, Indonesia
}

\begin{tabular}{|c|c|}
\hline Article Info & Abstract \\
\hline $\begin{array}{l}\text { Article History : } \\
\text { Received April } 2020 \\
\text { Accepted May } 2020 \\
\text { Published April } 2021\end{array}$ & \multirow{3}{*}{$\begin{array}{l}\text { STEM is one of the learning paradigms that integrates science, technology, } \\
\text { engineering and mathematics. The combination of several learning methods } \\
\text { is implemented to make students achieve certain abilities, like problem } \\
\text { solving skills. Problem solving becomes a very important part in learning } \\
\text { because it can motivate students and make them having a better cognitive } \\
\text { level. The purpose of this study is to describe the effect of STEM learning on } \\
\text { physics material applied in schools to the problem-solving abilities of } \\
\text { students. The method used in this research is meta-analysis where the } \\
\text { researcher analyzed several articles as needed. Articles were limited to the last } \\
5 \text { years of publication, namely } 2014 \text { - 2019. Searching for articles used the } \\
\text { Scholar, Eric, and Elsevier search engines. From the searching results, it was } \\
\text { obtained } 21 \text { relevant articles according to the needs of researchers. Then, from } \\
21 \text { articles that were obtained as many as } 86 \% \text { were research articles that used } \\
\text { questions or teaching materials as STEM-based learning media and } 14 \% \text { were } \\
\text { review articles. The keywords used in the search were STEM, problem } \\
\text { solving and physics. Based on the analysis conducted it can be concluded that } \\
\text { learning through the STEM approach can improve students' problem solving } \\
\text { abilities. }\end{array}$} \\
\hline $\begin{array}{l}\text { Keywords: } \\
\text { STEM, science, Problem } \\
\text { Solving }\end{array}$ & \\
\hline & \\
\hline
\end{tabular}

$\triangle$ correspondence :

SMP N 1 Banyubiru, Indonesia

p-ISSN 2252-6412

Jalan Melati No.19, Kampungrapet, Banyubiru, Semarang, Jawa

e-ISSN 2502-4523

Tengah, Indonesia 50664

E-mail: nurulheniastuti04@gmail.com 


\section{INTRODUCTION}

The development of the 21st century had an impact on society. One impact is seen in the education system. Technology as a source of information develops creative ideas, and improvisation in the scientific field (UNESCO, 2008). The development of information and communication technology (ICT) and its use is implied in learning (Farisi, 2016). The 21st century requires some preparations, one of the preparations that must be possessed is the problem solving ability (Hidayat, et al., 2017). In facing the globalization era, one's success in life is determined by one's thinking skills in solving problems (Susilo, 2012). Nugraheni, et al., (2014) stated that one of the fundamental goals in learning mathematics is that students have problem solving abilities. The ability of problem solving can be reflected in the way someone resolves problems accurately, precisely, in harmony, and rationally (Pistany, et al., 2015; Polya, 1971). However, it seems that Indonesia still needs a specific strategy to deal with this (Safitri, et al., 2019). Based on TIMSS data (Trends International Mathematics and Science Study) shows that Indonesia has a low level of scientific ability (IES, 2017).

The results of the 2016-2017 World Economic Forum showed that Indonesia experienced a decline in global competitiveness, from 37 to 41 (a total of 138 countries) (WEF, 2016). Problem solving skill can train someone to think critically, logically, and creatively (Sumarmo, 1994). A problem that is solved scientifically will make students dare to make decisions. Jonassen, et al (2010) states a problem contains conditions that encourage someone to solve it, only sometimes someone does not know how to solve the problem. One way to overcome a problem is to use a learning model. Learning models that can be used to improve problem solving skills are Project-Based Learning (PjBL), Problem Based Learning (PBL), and Discovery Learning. Learning models are selected and adapted to the material and characteristics of students (Afrina, et al., 2016). In addition to the learning model of the problem-based practical module, learning can also increase student independence (Fidina et al., 2012)

The application of $\mathrm{PjBL}$ in science learning can improve cognitive abilities (Baran \& Maskan,
2010), science process skills (Özer \& Özkan, 2012), and effective learning (Cook et al., 2012; Movahedzadeh et al., 2012). The PjBL learning model can help students construct initial knowledge (Capraro et al., 2013). In addition to PjBL learning, the application of PBL learning can improve students' cognitive levels, and problem solving abilities (Susilo, 2012). One learning model that is integrated and in accordance with the current era of globalization is STEM (Becker \& Park, 2011). STEM is one of the learning models that drives the success of the 21st century skills. The STEM learning system is integrated with several sciences, namely: science, technology, engineering, and mathematics. Through STEM learning, students have the ability, skills, and confidence in subjects through an interdisciplinary approach (Beers, 2011; Corlu et al., 2014).

The integration of STEM in learning can be seen in the activities of reading, writing, observing, and problem solving skills (Mayasari et al., 2014). STEM makes students have better, independent, and logical problem solving abilities (Stohlmann et al., 2012). STEM learning is expected to be meaningful to students through integrated knowledge, concepts, and skills (Afriana et al., 2016). STEM provides demand on students to solve problems and become well-defined outcomes through peer collaboration (Han et al., 2015). At present STEM learning is very important to solve global issues and problems facing the world (Reeve, 2015). STEM that has been integrated with problems makes students learn to solve problems. The application of effective STEM learning based on problem solving becomes one of the scopes of science skills (Permanasari, 2016; Adlim, et al., 2015; Nugraheni \& Suyanto, 2017). The purpose of this study is to provide an explanation of the STEM-based learning system to improve students' problem solving abilities.

\section{METHOD}

A literature review conducted systematically and structured is used to analyze and describe STEM-based learning. Through a systematic confirmation process by selecting items by MetaAnalysis (Soeharto et al., 2019). The steps taken are: (1) establishing subject criteria and operational definitions; (2) designing a search strategy; (3) 
searching and screening to identify; (4) describe and examine articles that have been obtained; and (5) doing synthesis. Researchers conducted an article search process with search engines Scholar, Eric, and Elsevier. They analyzed several articles by conducting special searches and restrictions on the year of publication. This study only concerned at the last 5 years of research, namely 2014 to 2019 . From the limitation, the researchers obtained 21 relevant articles. Keywords and article information are 1) year of publication, 2) research material (physics), 3) STEM learning, and 4) problem solving. After finding relevant articles, researchers conducted a STEM-based learning analysis to improve students' problem solving abilities. A literature review conducted is based on abstract analysis, research methods, instruments, and the results of STEM-based learning analysis to improve problem solving skills.

\section{RESULTS AND DISCUSSION}

STEM learning is one of the efforts to overcome human resources in the global era (Yulia
\& Ramli, 2019). STEM learning training is one way to introduce STEM in education (Chiu \& Money, 2011). The purpose of STEM learning itself is to integrate, implement problem-based learning (STEM Literacy). STEM learning can improve literacy (Sampurno et al., 2015; Ismail, 2016) and improve student learning outcomes (Becker \& Park, 2011). When someone has the ability to solve problems, students will correlate cognitive knowledge with thought activities (Tan, 2004; Izzaty, 2006). This makes the problem solving ability very important to be applied in learning (Cahyani \& Setyawati, 2016) and directs her knowledge of problem solving (Fitriyah et al., 2018). The results of the study from Astuti et al., (2020) stated that the ability of students in solving problems is still relatively low, namely by taking 2 schools and then giving 2 problem solving problems to be solved. The results of the comparison of problem solving abilities for the two schools are shown in Graph 1 and Graph 2 (Astuti et al., 2020).

The results of the comparison of two problem solving questions in school $\mathrm{A}$ are presented in graphical form as in Figure 1.

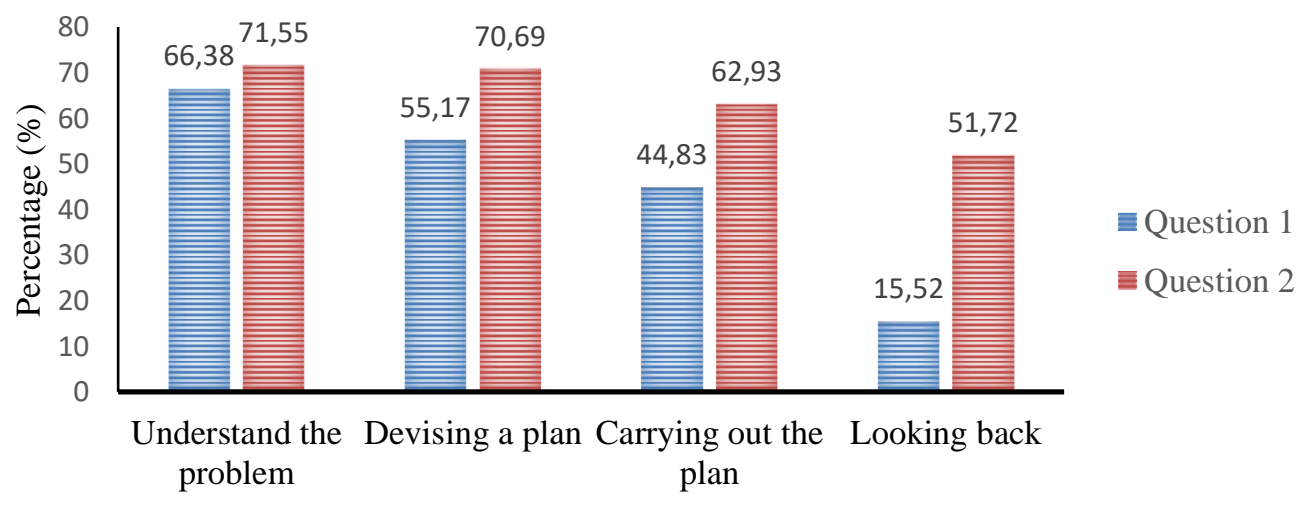

Figure 1. Comparative Score of School Problem Solving Ability A

The results of the comparison of two problem solving questions in school B are presented in graphical form as in Figure 2.

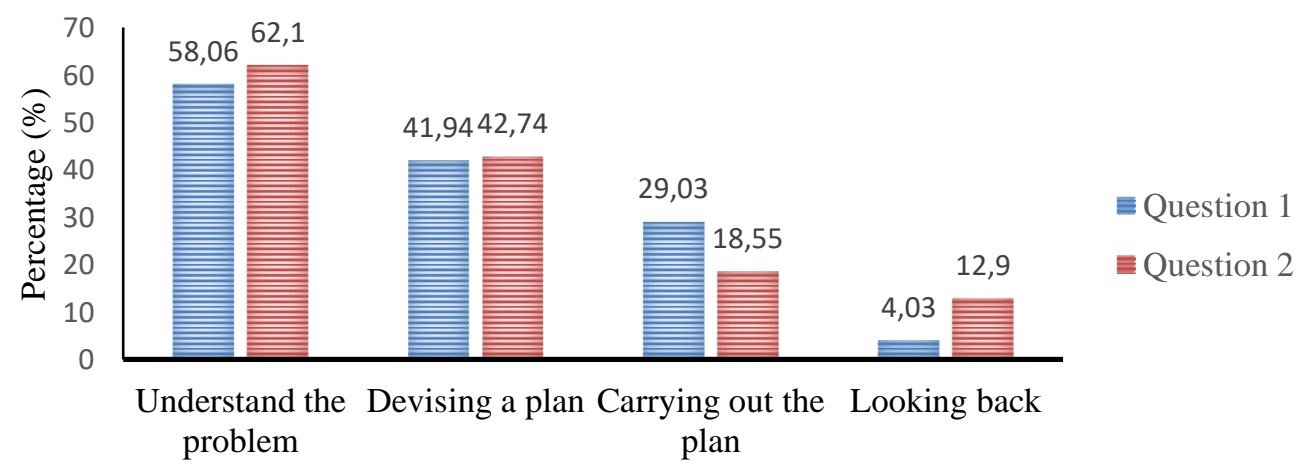

Figure 2. Comparative Score of School Problem Solving Ability 
Of the four indicators of problem solving Polya, $>50 \%$ of students are only able to achieve 2 indicators of problem solving in Polya, in which students are only able to understand and make plans (Astuti et al., 2020). Several studies have been conducted to investigate the use of STEM learning models that have an impact on learning. The results showed that STEM can encourage students to have the creativity and environmental literacy (Permanasari, 2016), affect professional abilities and social behavior (Surjanen, 2015). STEM is integrated with several scientific fields so that its existence becomes one of the solutions in the education system because students will be trained to understand a problem using the knowledge they have and to design solutions on them (Nava \& Prasetyo, 2018). Based on the results of the analysis of the article conducted, in general, it explains the effect of STEM in learning, especially on the problem solving abilities of students. Of the 21 articles analyzed $86 \%$ of articles were research results and $14 \%$ of articles were the result of review articles from several relevant articles. In the research article, it appears that the researchers used the experimental control method to see the difference between before and after condition being treated.

Alfika and Mayasari (2018) present essay questions that have been integrated with problem solving problems. Physics is expected to be able to make humans who have good problem solving skills by integrating various scientific studies and used to find solutions to existing problems. Physics consists of various abstract concepts, in studying it requires accuracy, steps, and media (Yusuf \& Widyaningsih, 2018). Problem solving skills are an investigative skill in developing solutions (Selcuk et al., 2008) and training students' critical thinking skills through learning to use concept maps to reduce misconceptions (Negoro et al., 2018). The ability of students to solve physics problems can be seen from the way students understand each physics concept and how students form strategies to solve problems (Docktor et al., 2016; Selcuk et al., 2008) The four stages that are often used in solving problems namely: understanding the problem, making plans, implementing plans, and evaluating problems (Yulianti et al., 2018). Solving problems is a form of scientific concept so that it becomes the basic concept of scientific literacy which includes elements of scientific inquiry and scientific knowledge (Abd-El-Khalick et al., 2004; Nentwig, et al., 2009). STEM can improve problem solving skills in students in several ways, one of them by making a module or teaching materials based on STEM. The STEM approach uses physics teaching materials that are integrated with local wisdom (Alfika \& Mayasari, 2018) can improve student learning outcomes inside or outside school (Nurazizah et al., 2018).

STEM learning makes students more experienced in solving problems because students are given the freedom to design. Students more easily remember and master technology (Kaniawati et al., 2015). If students are used to integrating problems with STEM will help students think critically, logically, and systematically (Kaniawati et al., 2015). STEM learning that was designed to support the success of the 21st century was not in line with the readiness of teachers to accept STEM learning. The lack of will in learning STEM makes STEM unable to be implemented well (Siew et al., 2015; El-Deghaidy \& Mansour, 2015; E1-Deghaidy et al., 2017). Some training has been held, it's just that the time is too short to make the training not run optimally (Siew, 2015; Duran et al., 2013). The implementation of STEM needs to consider the material and look at research studies (Thibaut et al., 2018).

Seeing the impact of STEM activities in improving problem solving skills, it is necessary to evaluate each lesson (Han et al., 2014). The results of the research of Dewi et al., (2018) showed an increase in the ability of problem solving in students after STEM-based learning. The results of the study can be seen in the Table. 1

Table 1. Pretest and Posttest Results of Problem Solving Ability

\begin{tabular}{|c|c|c|c|c|}
\hline & \multicolumn{2}{|c|}{ Average } & \multirow[t]{2}{*}{$\mathrm{N}$ - Gain } & \multirow[t]{2}{*}{ Information } \\
\hline & Pretest & Postest & & \\
\hline Problem & 16.11 & 96.81 & 0.69 & Middle \\
\hline \multicolumn{5}{|l|}{ Solving } \\
\hline 1 & 46.05 & 86.32 & 0.73 & High \\
\hline 2 & 24.74 & 87.02 & 0.82 & High \\
\hline 3 & 4.21 & 70.00 & 0.69 & Middle \\
\hline 4 & 1.58 & 60.00 & 0.60 & Middle \\
\hline 5 & 0.00 & 68.82 & 0.69 & Middle \\
\hline
\end{tabular}

Based on Table 1, it can be seen that there is a significant difference between the pretest and 
posttest questions, it can be seen how much increase in each stage, using normalized $\mathrm{N}$-gain can be seen an increase (Dewi et al., 2018). The post-test results showed a fairly high average value at each stage (Dewi et al., 2018). The problems faced by the global community today are increasingly complex and continue to change every time so it requires multidisciplinary science and many STEM integration needs in solving problems, if the integration of STEM is less appropriate it will lead to unclear STEM education itself (Wang, et al., 2011). Each student has different thoughts in solving problems (Lasiani and Rusilowati, 2017) so that the presence of STEM to improve problem solving skills does not only have an impact on students but also has an impact on teachers (Yildirim \& Sidekli, 2018). Teachers will have better pedagogical abilities than before (Yildirim \& Sidekli, 2018).

Teachers need support from various fields of science because of the integration of complex STEMs so that teachers must learn more about technology (Ntemngwa \& Oliver, 2018). STEM learning is an interdisciplinary approach that ensures every student can play an active role in learning (Yildirim \& Sevi, 2016), this is done to see the improvement in problem solving abilities of each student. Wahoyo \& Chang's research results (2019) mention STEM integrated learning makes students more interested and active in learning science. The sex of students can also affect the ability of problem solving in integrating STEM (Park et al., 2016). STEM is commonly used in primary schools rather than junior high schools and senior high schools (Park et al., 2016). Schools realize that implementing STEM requires preparation from the school environment where school management and school structures are needed (Debes, 2018; Huet, 2017). The availability of educational materials and resources is often a significant problem (Kim et al., 2019).

\section{CONCLUSION}

Based on the results of the review of articles that have been found, several factors have found that STEM learning is a learning solution, especially in improving problem solving skills. The integrated STEM is expected to be able to overcome the current problems. STEM learning can encourage students to construct initial knowledge and be good problem solvers. Moreover, STEM learning can make students to have higher motivation and systematic way of thinking. Also, they become more critical and creative in the process of learning. Therefore, STEM learning becomes a learning model in accordance with the current era of globalization because it can answer the problem of multidisciplinary science.

\section{REFERENCES}

Abd-El-Khalick, F., Boujaoude S., Duschl R., Lederman, N.G., Mamlok-Naaman, R., Hofstein A.,Niaz, M., \& Treagust D. (2004). Inquiry in Science Education: International Perspectives.Science Education, 88 : 397-419

Adlim, M., Saminan.,\& Ariestia, S. (2015). Pengembangan Modul STEM Terintegrasi Kewirausahaan untuk Meningkatkan Keterampilan Proses Sains di SMA Negeri 4 Banda Aceh. Jurnal Pendidikan Sains Indonesia, 3(2) :112-121.

Afriana, J., Permanasari, A., \& Fitriani, A. (2016). Penerapan Project Based Learning Terintegrasi STEM untuk Meningkatkan Literasi Sains Siswa Ditinjau dari Gender. Jurnal Inovasi Pendidikan IPA, 2 (2): 202 - 212.

Alfika, Z.A., \& Mayasari, T. (2018). Profil kemampuan memecahkan masalah pelajaran fisika siswa MTS. Seminar Nasional Quantum, 583-589, ISSN :24771511.

Astuti, N.H., Rusilowati, A., Subali, B., \& Marwoto, P. (2020). Analisis Kemampuan Pemecahan Masalah Model Polya Materi Getaran, Gelombang, dan Bunyi Siswa SMP. UPEJ, 9 (1) : 1-8.

Baran, M., \& Maskan, A. (2010). The Effect of Projectbased learning on pre-service physics teachers'electrostatic achievements. Cypriot Journal of Educational Sciences, 5, 243-257.

Becker, K., \& Park, K. (2011). Effects of integrative approaches among science, technology, engineering, and mathematics (STEM) subjects on students' learning: A preliminary metaanalysis. Journal of STEM Education, 12(5) : 23-37

Beers, S. Z. (2011). 21st Century Skills: Preparing Students For Their. Future.URL:https://www.yinghuaacade my.org/wpcontent/uploads/2014/10/21st _century_skills.pdf

Cahyani, H., \& Setyawati, R. W. (2016). Pentingnya Peningkatan Kemampuan Pemecahan Masalah melalui PBL untuk Mempersiapkan Generasi 
Unggul Menghadapi MEA. Seminar Nasional Matematika X Universitas Negeri Semarang, 151-160.

Capraro, R. M., Capraro, M. M., Morgan, J. R., \& Slough, S. W. (2013). STEM ProjectBased Learning: An Integrated Science, Technology, Engineering, and Mathematics (STEM) Approach. STEM Project-Based Learning an Integrated Science, Technology, Engineering, and Mathematics (STEM) Approach. http://doi.org/10.1007/978-94-6209-143-6

Chiu, M.-H., \& Duit, R. (2011). Globalization: Science education from an international perspective. Journal of Research in Science Teaching, 48(6) : 553566. doi:10.1002/tea.20427

Corlu, M. S., Capraro, R. M., \& Capraro, M. M. (2014). Introducing STEM education: Implications for educating our teachers in the age of innovation. Education and Science, 39(171) : 74-85.

Cook, K., Buck, G., \& Park Rogers, M. (2012). Preparing biology teachers to teach evolution in a project-based approach. Science Educator, 21(2) : 18-30. Doi :https://eric.ed.gov/?id=EJ997503

Debeş, G. (2018). Effects of STEM Education Seminars on Teachers in the Schools of North Cyprus. Eurasia Journal of Mathematics, Science and Technology Education, 14(12) :1-7. doi:10.29333/ejmste/91090

Dewi, M., Kaniawati, I, Suwarma, I.R. (2018). Penerapan Pembelajaran Fisika Menggunakan Pendekatan STEM Untuk Meningkatkan Kemampuan Memecahkan Masalah Siswa Pada Materi Listrik Dinamis. Seminar Nasional Quantum, 381-385.

Docktor, JL., Dornfeld, J., Frodermann E, Heller, K., Hsu, L., Jackson, K.A., \& Yang J. (2016)Assessing student written problem solutions: A problem solving rubric with application tointroductory physics. Physical Review Physics Education Research, 12(1) : 10130-1 - 1013018.

Duran, M., Höft, Margret., Lawson, B., Medjahed, B., \& Orady, E. A. (2013). Urban High School Students' IT/STEM Learning: Findings from a Collaborative Inquiry- and Design-Based Afterschool Program. Journal of Science Education and Technology, 23, doi : 10.1007/s10956-0139457-5.

El-Deghaidy, H., \& Mansour, N. (2015). Science Teachers' Perceptions of STEM Education: Possibilities and Challenges. International Journal of Learning and Teaching, 1(1) : 51-54.

EL-Deghaidy, H., Mansour, N., Alzaghibi, M., \&Alhammad, K. (2017). Context of STEM Integration in Schools: Views from In-service Science Teachers. Eurasia Journal of Mathematics,
Science and Technology Education, 13(6) : 2459-2484. https://doi.org/10.12973/eurasia.2017.01235a.

Farisi, M.I. (2016). Developing The $21^{\text {st }}$-Century Social Studies Skills Through Technology Integration. Turkish Online Journal of Distance Education, 17 (1), 16-30

Fidiana, L., Subali, B., \& Pratiwi. (2012). Pembuatan Dan Implementasi Modul Praktikum Fisika Berbasis Masalah Untuk Meningkatkan Kemandirian Belajar Siswa Kelas XI. UPEJ, 1 (1) : 39-44

Fitriyah., Sumpono, I., \& Subali, B. (2018). Implementasi Alat Praktikum Pembiasan Cahaya untuk Meningkatkan Kemampuan Pemecahan Masalah Siswa SMA. Unnes Physics Education Journal, 7(3) : 75-84.

Han, S., Capraro, R., \& Capraro, M. M. (2014). How Science, Technology, Engineering, And Mathematics (Stem) Project-Based Learning ( $\mathrm{Pbl}$ ) Affects High, Middle, And Low Achievers Differently: The Impact Of Student Factors On Achievement. International Journal of Science and Mathematics Education, 13(5) :1089-1113. doi:10.1007/s10763-014-9526-0

Hidayat, S. R., Setyadin, A. H., Hermawan, H., Kaniawati, I., Suhendi, E., Siahaan, P., \& Samsudin, A. (2017). Pengembangan Instrumen Tes Keterampilan Pemecahan Masalah pada Materi Getaran, Gelombang, dan Bunyi. Jurnal Penelitian \& Pengembangan Pendidikan Fisika, 3(2) :157 -166. https://doi.org/10.21009/1.03206

Huet, I. (2017). Research-Based Education As A Model To Change The Teaching And Learning Environment In STEM Disciplines. European Journal of Engineering Education, 43(5) :725740.doi:10.1080/03043797.2017.1415299

IES. (2017). Highlights From TIMSS and TIMSS Advanced 2015. from IES National Center for Education Statistics: http://nces.ed.gov/pubs2017/tim ss

Ismail, A. (2016). STEM Virtual Lab : An Alternative Practical Media to Enhace Student's Scientific Literacy. Jurnal Pendidikan IPA Indonesia, 5(2) :239-246

Izzaty, R.E. (2006). Problem Based Learning dalam Pembelajaran di Perguruan Tinggi. Paradigma, (1) :77 - 83 .

Jonassen, D., Mateycik, F., \& Rebello, N.S. (2010). Students' Rating of Problem Similarity as a Measure of Problem Solving Expertise. Proceedings of the 2010 Annual Meeting of the National Association for Research in Science Teaching, 2-20

Kaniawati, D.S., Kaniawati, I., \& Suwarma, I.R. (2015). Study Literasi Pengaruh Pengintegrasian Pendekatan StemDalam Learning Cycle 5e 
Terhadap Kemampuan PemecahanMasalah Siswa Pada Pembelajaran Fisika. Seminar Nasional Fisika (SINAFI), 39-48, ISBN: 978-602-74598-0-9.

Kim, M. K., Lee, J. Y., Yang, H., Lee, J., Jang, J. N., \& Kim, S. J. (2019). Analysis of Elementary School Teachers' Perceptions of Mathematics-Focused STEAM Education in Korea. Eurasia Journal of Mathematics, Science and Technology Education, 15(9) : 1-13. doi:10.29333/ejmste/108482

Lasiani \& Rusilowati, A. (2017). Pola Pemecahan Masalah Berdasarkan Representasi Siswa Dalam Membangun Pemahaman Konsep Fisika. Physics Communication, 1(1): 1-7.

Mayasari, T., Kadorahman, A., \& Rusdiana, D. (2014). Pengaruh Pembelajaran Terintegrasi Science, Technology, Engineering, And Mathemathics (STEM) Pada Hasil Belajar Peserta Didik: Studi Meta Analisis. Surabaya: UNESA Prosiding Semnas Pensa VI "Peran Literasi Sains", 371-377.

Movahedzadeh, F., Patwell, R., Rieker, J. E., \& Gonzalez, T. (2012). Project-Based Learning To Promote Effective Learning In Biotechnology Courses. Education Research International, 1-8. http://doi.org/10.1155/2012/536024

Nava, T.H.N.S.,\& Prasetyo, Z.K. (2018). Pengaruh Pendekatan SocioScientific Issues Berbasis STEM Terhadap Literasi Sains Siswa. EJournal Pendidikan IPA, 7(5) : 162-166

Nugraheni, S., Sugianto, S., \& Rusilowati, A. (2019). Implementasi Model Pembelajaran "Treffinger" untuk Meningkatkan Kreativitas dan Kemampuan Pemecahan Masalah Siswa SMA. Unnes Physics Education Journal, 8 (2) : 162-169

Nugraheni, D., \& Suyanto, S. (2017). Pengaruh Siklus Belajar 5e Terhadap Kemampuan LiterasiSains Pada Materi Sistem Saraf Manusia. Jurnal Prodi Pendidikan Biologi, 6(4) :178-179.

Nurazizah.,Suwarma, S.I, Jauhari, A., \&Kaniawati I. (2018). Implementasi Pembelajaran STEM: Kajian Terhadap Pencapaian Hasil Belajar Siswa.Prosiding Seminar Nasional Fisika (SINAFI), 126-130.ISBN: 978-602-74598-2-3.

Nentwig, P., Roennebeck, S., Schoeps, K., Rumann, S., \& Carstensen, C. (2009). Performance and levels of contextualization in a selection of OECD countries in PISA 2006. Journal of Research in Science Teaching, 46(8) : 897-908. doi:10.1002/tea.20338

Negoro, R. A., Hidayah, H., Rusilowati, A.,\&Subali, B. (2018). Upaya Membangun Ketrampilan Berpikir Kritis MenggunakanPeta Konsep Untuk Mereduksi Miskonsepsi Fisika. Jurnal Pendidikan (Teori dan Praktik), 3(1) : 45-51

Ntemngwa, C. \& Oliver, J.S. (2018). The Implementation of Integrated Science Technology, Engineering and Mathematics (STEM) Instruction using
Robotics in the Middle School Science Classroom. International Journal of Education in Mathematics, Science and Technology (IJEMST), 6(1) : 12-40. DOI:10.18404/ijemst.380617

Özer, D. Z. \& Özkan, M. (2012). The Effect Of The Projectbased Learning On The Science Process Skills OfThe Prospective Teachers Of Science. Journal ofTurkish Science Education, 9 (3): 131-136.

Park, H., Byun, S., Sim, J., Han, H., \& Baek, Y. S. (2016). Teachers' Perceptions and Practices of STEAM Education in South Korea. Eurasia Journal of Mathematics, Science and Technology Education, $12(7)$ : 1739-1753. https://doi.org/10.12973/eurasia.2016.1531a

Pistanty, M. A., Sunarno, W., \& Maridi, M. (2015). Pengembangan Modul IPA Berbasis Problem Based Learning untuk Meningkatkan Kemampuan Memecahkan Masalah pada Materi Polusi serta Dampaknya pada Manusia dan Lingkungan Siswa Kelas XI SMK Pancasila Purwodadi. Jurnal Inkuiri ,4(2): 67- 75

Permanasari, A. (2016). STEM Education:Inovasi dalam Pembelajaran Sains. Seminar Nasional Pendidikan Sains , 23- 30.

Polya, G. (1971). How To Solve It: A New Aspect of Mathematical Method.USA. Princeton University Press, Princeton, New Jersey.

Reeve, E.M. (2015). STEM thinking!.Technology and Engineering Teacher(ITEEA), 74 (4): 8-16

Safitri, Y., Mayasari, T., \& Handhika J. (2019). Interdiciplinary Stem Module Of Guitar Based Scientific Literacy: Modul Stem Pada Gitar Berbasis Literasi Sains. Seminar Nasional, Hasil Penelitian dan Pengabdian kepada Masyarakat UNIPMA, 109-115.

Sampurno, P.J., Sari, Y.S., \& Wijaya, A. G. (2015). Integrating STEM (Science, Technology,Engineering, Mathematics) and Disaster (STEMD) Education for Building Students'disaster Literacy. InternationalJournal of Learning and Teaching, 1(1) : 73-76

Siew, N. M., Amir, N., \& Chong, C. L. (2015). The Perceptions Of Pre-Service And In-Service Teachers Regarding A Project-Based STEM Approach To Teaching Science. SpringerPlus, 4(1). doi:10.1186/2193-1801-4-8

Selçuk, G.S, Çal S., \& Erol, M.(2008) The Effects of Problem Solving Instruction on PhysicsAchievement, Problem Solving Performance, and Strategy Use.Journal Physics Education,2(3): 151-166

Soeharto., Csapó, B., Sarimanah. E., Dewi, F. I.,\&Sabri, T. (2019).A Review Of Students Common Misconceptions In Science And Their Diagnostic Assessment Tools. Jurnal Pendidikan IPA Indonesia, 8 (2): 247-266. 
Susilo, A.B. (2012). Pengembangan Model Pembelajaran IPA Berbasis Masalah Untuk Meningkatkan Motivasi Belajar dan Berpikir Kritis Siswa SMP. Journal of Primary Educational, 1(1): 57-63

Surjanem, R. (2015). Profil keterampilan Berpikir Kritis Dan Kemampuan Pemecahan MasalahFisika Siswa SMA Negeri di Kota Singaraja. Jurnal pendidikan sains. 228-231.

Sumarmo, U. (1994). Pengembangan Berpikir Matematik Tinkgat Tinggi Siswa SLTP dan SMU Serta Mahasiswa Strata Satu (S1) Melalui Berbagai Pendekatan Pembelajaran. Laporan Hibah penelitian Pascasarjana Tahun Ketiga : tidak diterbitkan

Stohlmann, M., Moore, T. J., \& Roehrig, G. H. (2012). Considerations for teaching integrated STEM education. Journal of Pre-College Engineering Education Research Journal of Pre-College Engineering Education ResearchJ-PEER). Journal of Pre-College Engineering Education Research, 2(2): 1-28. http://doi.org/10.5703/1288284314653

Tan, O.S. (2004). Cognition, Metacognition, and ProblemBased Learning. In Tan, OOn Seng (Ed). Enhancing Thinking through Problem Based LearningApproaches. Singapure: Thomson.

Thibaut, L., Ceuppens, S., De Loof, H., De Meester, J., Goovaerts, L., Struyf, A., Boeve-de Pauw, J., Dehaene, W., Deprez, J., De Cock, M., Hellinckx, L., Knipprath, H., Langie, G., Struyven, K., Van de Velde, D., Van Petegem, P., \& Depaepe, F. (2018). Integrated STEM Education: A Systematic Review of Instructional Practices in Secondary Education. European Jourrnal of STEM Education, 3(1) : 02-12. doi : https://doi.org/10.20897/ejsteme/85525

UNESCO. (2008). UNESCO ICT Competency Framework for Teachers. Prancis: UNESCO and Microsoft 2011.

Wang, Hui-Hui., Moore, T.J., Roehrig, G.H., \& Park, M.S. (2011). "STEM Integration: Teacher
Perceptions and Practice. Journal of Pre-College Engineering Education Research (J-PEER), 1(2) : 114. https://doi.org/10.5703/1288284314636

Wahono, B., \& Chang, C.Y. (2019). Assessing Teacher's Attitude, Knowledge, and Application (AKA) on STEM: An Effort to Foster the Sustainable Development of STEM Education. Sustainability, 11(4) : 950. doi:10.3390/su11040950

World Economic Forum (WEF). (2016). Competitive Cities and Their Connections to Global

Y1ldırım, B., \& Sidekli, S. (2018). Stem Applications In Mathematics Education: The Effect Of STEM Applications On Different Dependent Variables. Journal of Baltic Science Education, 17(2): 200-214

Yildırım, B., \& Sevi, M. (2016). Examination Of The Effects Of STEM Education Integrated As A Part Of Science, Technology, Society And Environment Courses. Journal of Human Sciences, 13(3): 3684-3695. Retrieved from https://www.j humansciences.com/ojs/index.php/IJHS/article/ view/3876

Yusuf, 1.,\& Widyaningsih, S.W. (2018). HOTS Profile Of Physics Education Students In STEMBasedClasses Using PhET Media. International Conference on Mathematics and Science Education (ICMSCE), $\quad 1-5, \quad$ doi:10.1088/17426596/1157/3/032021

Yuliati, L., Parno., Hapsari, A.A., Nurhidayah, F.L.,\& Halim, L. (2018). Building Scientific Literacy and Physics Problem SolvingSkills through InquiryBased Learning for STEM Education. Journal of PhysicS, 1108 (2018): 1-6, doi :10.1088/17426596/1108/1/012026.

Yulia, S.R., \& Ramli, R. (2019). AnalisisKebutuhan Pengembangan Handout Berbasis STEM Terhadap Pembelajaran Fisika dalam Menghadapi Era Revolusi Industri 4.0. Jurnal Penelitian Pembelajaran Fisika, 5(1) : 42-48. 